\title{
PERANAN BADAN NARKOTIKA NASIONAL (BNN) KABUPATEN BLITAR DALAM UPAYA PENCEGAHAN PENYALAHGUNAAN NARKOTIKA PADA RUANG LINGKUP SEKOLAH DI KABUPATEN BLITAR
}

Brian Yuda Wibawa, Mahasiswa Fakultas Hukum Universitas Islam Balitar, Blitar, Indonesia, E-mail: byuda03@gmail.com

\begin{abstract}
ABSTRAK
Tujuan dari penelitian ini adalah untuk mengetahui peranan dan kendala-kendala Badan Narkotika Nasional (BNN) Kabupaten Blitar dalam upaya pencegahan penyalahgunaan narkoba pada ruang lingkup sekolah. Penelitian yuridis empiris di Kecamatan Wlingi Kabupaten Blitar ini menunjukkan bahwa peranan BNN Kabupaten Blitar dalam upaya pencegahan penyalahgunaan narkoba di lingkup sekolah sudah baik karena tugas pokok dan fungsinya sebagian besar sudah terealisasi. Kendala-kendala yang dihadapi BNN Kabupaten Blitar berasal dari faktor internal hukum, faktor sarana dan prasarana, serta pihak sekolah.
\end{abstract}

Kata Kunci: Badan Narkotika Nasional (BNN), Pencegahan, Ruang Lingkup Sekolah

\section{PENDAHULUAN}

Narkotika adalah zat atau obat yang berasal dari tanaman atau bukan tanaman, baik sintetis maupun semi sintetis yang dapat menyebabkan penurunan atau perubahan kesadaran, hilangnya rasa nyeri dan dapat menimbulkan ketergantungan. ${ }^{1}$ Narkotika memiliki daya adiksi (ketagihan), daya toleran (penyesuaian), daya habitual (kebiasaan) yang sangat kuat, sehingga menyebabkan pemakai narkotika tidak dapat lepas dari pemakaiannya. ${ }^{2}$ Dampak penyalahgunaan narkotika meliputi dampak fisik, psikologis, dan sosial. Dampak fisik misalnya gangguan pada sistem saraf (neurologis), kejang-kejang, halusinasi, dan gangguan kesadaran. Dampak psikologis berupa perasaan kesal dan tertekan. Dampak sosial misalnya dikucilkan oleh lingkungan.

Masalah penyalahgunaan narkotika di Indonesia saat ini sudah sangat memperihatinkan. Hal ini terlihat dengan semakin banyaknya penyalahguna dan peredaran narkotika dari semua kalangan yang terus meningkat. Ancaman narkoba di Indonesia semakin meningkat dan mengarah kepada generasi muda terdidik. Bahkan kini mulai merambah kepada keterlibatan aparat negara. Sekarang, Indonesia tidak lagi sekedar menjadi wilayah transit atau wilayah pemasaran narkotika ataupun zat-zat adiktif lainnya, tetapi telah menjadi produsen dan eksportir obat-obatan terlarang. ${ }^{3}$

Melihat kenyataan yang terjadi dan dampak negatifnya yang sangat besar dimasa yang akan datang, maka semua elemen bangsa ini, seperti pemerintah, aparat penegak hukum, institusi pendidikan, masyarakat dan lain sebagainya melakukan gerakan memerangi narkotika secara serius dan terus menerus. Sehingga, upaya pencegahan dan penanggulangan narkotika ini dapat berjalan dengan efektif. Dalam rangka pencegahan dan pemberantasan penyalahgunaan narkotika maka dibentuklah Badan Narkotika Nasional (BNN). Pembentukan BNN sendiri berdasarkan atas landasan hukum yang telah

${ }^{1}$ Heldy Chandra, dkk, Peranan Badan Narkotika Nasional Provinsi Dalam Pencegahan Dan Penanggulangan Peredaran Narkotika di Provinsi Sulawesi Selatan, artikel, hlm 1.

2 Joyo Nur Suryanto Gono, Narkoba: Bahaya Penyalahgunaan dan Pencegahannya, artikel, hlm 81.

${ }^{3}$ Kadarmanta, A. Narkoba Pembunuh Karakter Bangsa. Jakarta: PT. Forum Media Utama. hlm 9. 
ditetapkan, yang tercantum dalam Peraturan Presiden Republik Indonesia Nomor 23 Tahun 2010 tentang Badan Narkotika Nasional. ${ }^{4}$

Badan Narkotika Nasional (BNN) adalah lembaga pemerintahan non kementerian yang berkedudukan di bawah presiden dan bertanggung jawab kepada presiden. Berdasarkan UU Nomor 35 Tahun 2009 tentang Narkotika, BNN diberikan kewenangan penyelidikan dan penyidikan tindak pidana Narkotika dan prekursor Narkotika. BNN memiliki kewenangan memberikan pembinaan kepada masyarakat tentang bahaya narkotika, mendorong dan menggugah kesadaran masyarakat untuk tidak mengkonsumsi narkotika, serta membangktikan peran aktif serta kepedulian masyarakat untuk memerangi narkotika. BNN sebagai lembaga independen diharapkan dapat bekerja lebih baik serta transparan dan akuntabel dalam menumpas kejahatan narkotika.

Berdasarkan data penelitian BNN Kabupaten Blitar, jumlah pengguna narkoba mengalami peningkatan dari tahun ke tahun. Mendekati akhir tahun 2016, jumlah pengguna NAPZA di Kabupaten Blitar mencapai angka 3041 orang, dari jumlah tersebut 2765 (1,9\%) adalah pengguna psikotropika sedangkan $276(0,19 \%)$ adalah pengguna narkotika. ${ }^{5}$ Menurut Kepala BNN Kabupaten Blitar, AKBP Henry Siswanto, sesuai data di tahun 2015 jumlah tersebut mengalami peningkatan jika dibanding tahun-tahun sebelumnya.

Jumlah pengguna NAPZA berdasarkan jenis pekerjaan di Kabupaten Blitar adalah sebagai berikut: $40 \%$ remaja putus sekolah, $20 \%$ orang dewasa $10 \%$ kalangan pelajar, $20 \%$ kalangan umum, dan $5 \%$ kalangan pegawai atau karyawan. Sedangkan pengguna narkoba berdasarkan jenis kelamin adalah $25,49 \%$ pengguna narkotika adalah wanita dan $74,5 \%$ pengguna narkotika adalah pria. ${ }^{6}$

Berdasarkan data tersebut, penyalahgunaan narkotika di kalangan pelajar telah mencapai taraf memprihatinkan. Generasi muda merupakan aset penting masa depan bangka, jika para pelajar tidak membentengi diri dari penyalahgunaan narkotika, maka bangsa ini akan kalah dalam persaingan global di masa yang akan datang. Oleh karena itu tugas dan peran pemerintah melalui BNN baik di tingkat pusat, provinsi dan kabupaten/kota, sangat diperlukan dalam upaya pencegahan penyalahgunaan narkotika di lingkungan sekolah.

Dari uraian diatas, maka penelitian "Peranan Badan Narkotika Nasional (BNN) Kabupaten Blitar Dalam Upaya Pencegahan Penyalahgunaan Narkotika Pada Ruang Lingkup Sekolah di Kabupaten Blitar" urgen diperlukan guna mengetahui peranan dan kendala-kendala Badan Narkotika Nasional (BNN) Kabupaten Blitar dalam upaya pencegahan penyalahgunaan narkotika pada ruang lingkup sekolah.

\section{METODE PENELITIAN}

Penelitian ini menggunakan metode kualitatif yaitu penelitian yang menggunakan pendekatan kualitatif bertujuan untuk mengeksplorasi dan mencari penjelasan realita. ${ }^{7}$ Sedangkan menurut Muhadjir (1996) penelitian kualitatif adalah penelitian yang mengarah

\footnotetext{
${ }^{4}$ Badan Narkotika Nasional. Pedoman Petugas Penyuluhan P4GN Dilingkungan Hukum. (Jakarta: Badan Narkoyika Nasional, 2009). hlm 74.

${ }^{5}$ Data diperoleh dari Laporan Kesatuan BNN Kabupaten Blitar Tahun 2016

${ }^{6}$ Data diperoleh dari Laporan Kesatuan Badan Narkotika Nasional (BNN) Kabupaten Blitar

7 Bungin Burhan, (2001). Metodelogi Penelitian Kualitatif, Jakarta, Rajawali. 2001.
} 
penelitian proses dan biasanya membatasi pada satu kasus. ${ }^{8}$ Oleh karena itu dalam penelitian ini difokuskan pada bagaimana peranan Badan Narkotika Nasional (BNN) Kabupaten Blitar dalam upaya pencegahan penyalahgunaan narkotika pada ruang lingkup sekolah di Kecamatan Wlingi Kabupaten Blitar. Penelitian ini dilakukan melalui pendekatan yuridis empiris dengan data primer dan sekunder, dimana masing-masing data diperoleh dari penelitian kepustakaan dan dilapangan. Analisis data dideskripsikan dalam bentuk uraian kalimat yang kemudian berdasarkan fakta-fakta yang bersifat khusus dapat ditarik kesimpulan.

Adapun yang digunakan sebagai sumber data pada penelitian ini adalah sumber data primer dan sekunder. ${ }^{9}$ Data primer adalah data yang diperoleh langsung dari sumber pertama. Data yang dimaksud merupakan data yang diperoleh langsung dari BNN Kabupaten Blitar yaitu melalui pengumpulan dokumen, wawancara/interview, dan pengamatan/observasi. Data sekunder adalah data yang telah dikumpulkan oleh pihak lain atau biasanya telah di kumpulkan oleh lembaga pengumpul data dan dipublikasikan kepada masyarakat pengguna data. Data sekunder dalam penelitian ini adalah data yang diperoleh dari literatur-literatur dan bahan-bahan hukum yang relevan dengan permasalahan dalam penelitian ini. Data sekunder digunakan untuk melengkapi data primer apabila membutuhkan sumber data literature dan bahan hukum/undang-undang. Bahan hukum yang digunakan dalam penelitian ini adalah Undang-Undang Dasar Negara Republik Indonesia Tahun 1945, Undang-Undang Nomor 35 Tahun 2009 tentang Narkotika, Undang-Undang Nomor 5 Tahun 1997 tentang Psikotropika, serta peraturan perundangundangan yang masih terkait dan masih berlaku di Indonesia.

Guna mengumpulkan data-data yang digunakan dalam penelitian ini, maka pendekatan metode pengumpulan datanya adalah observasi, wawancara, dan dokumentasi. ${ }^{10}$ Observasi adalah pengamatan dan pencatatan suatu objek dengan sistematika fenomena yang diselidiki. Tujuan dari observasi adalah untuk mendeskripsikan setting, kegiatan yang terjadi, orang yang terlibat di dalam kegiatan, waktu kegiatan dan makna yang diberikan oleh para pelaku yang diamati tentang peristiwa yang dilakukan. Dalam penelitian ini peneliti mengamati dengan melihat kegiatan-kegiatan yang dilakukan BNN Kabupaten Blitar dalam upaya pencegahan penyalahgunaan narkoba di ruang lingkup sekolah di Kecamatan Wlingi Kabupaten Blitar. Wawancara atau interview adalah proses tanya jawab lisan dimana dua orang atau lebih berhadapan secara fisik yang satu dapat melihat muka yang lain dan mendengar dengan telinga sendiri dari suaranya. Wawancara ini dilakukan antara peneliti dengan staf BNN Kabupaten Blitar atau pihak lain yang berhubungan dengan objek yang diteliti. Cara untuk melakukan wawancara dalam penelitian ini adalah melalui percakapan informal (interview bebas). Dokumentasi berasal dari kata dokumen yang artinya barang-barang tertulis didalam melaksanakan metode ini penulis mencari data mengenai hal-hal atau variabel yang berupa catatan transkrip, internet, notulen rapat, surat kabar, majalah, dokumen, dan buku-buku. Metode ini digunakan untuk mengumpulkan dokumen yang ada pada lembaga atau instansi yang terkait atau bahan-

\footnotetext{
${ }^{8}$ Muhajir, H.N. (1996). Metodologi Penelitian Kualitatif. Edisi II, Rake Sarasin, Yogyakarta.

${ }_{9}$ Amirudin, Asikin, Z. 2004. Pengantar Metode Penelitian Hukum. Jakarta: PT RajaGrafindo Persada. hlm 30-31

10 Ashsofa, B. 2004. Metode Penelitian Hukum. Jakarta:PT Rineka Cipta. Hlm 58-59
} 
bahan yang tertulis yang berkaitan dengan situasi latar belakang objek penelitian dan ini sebagai pelengkap. Dokumentasi yakni dilakukan pada saat pelaksanaan penelitian di lapangan. Cara memperoleh data dengan menggunakan alat-alat seperti kamera, rekaman dan handycam.

Terkait hal tersebut di atas, maka metode analisis data yang digunakan dalam penelitian ini adalah analisis kualitatif. Menurut Bogdan \& Biklen analisis kualitatif adalah upaya yang dilakukan dengan jalan bekerja dengan data, mengorganisasikan data, memilah-milahnya menjadi satuan yang dapat dikelola, mensistesiskannya, mencari dan menemukan pola, menemukan apa yang penting dan apa yang dipelajari. ${ }^{11}$ Analisis data kualitatif dalam hal ini dilakukan terhadap data berupa informasi, uraian dalam bentuk prosa kemudian dikaitkan dengan data lainnya untuk mendapatkan kejelasan terhadap suatu kebenaran/sebaliknya, sehingga memperoleh gambaran yang ada. Dan sebaliknya jadi bentuk analisis ini merupakan penjelasan-penjelasan, bukan angka-angka statistik/bentuk angka lainnya.

\section{PEMBAHASAN}

Dalam penelitian ini, peneliti memfokuskan pada peranan Badan Narkotika Nasional (BNNK) Kabupaten Blitar dalam bidang pencegahan pada ruang lingkup sekolah di Kecamatan Wlingi Kabupaten Blitar. Komponen kegiatan yang telah ditetapkan oleh Badan Narkotika Nasional (BNNK) Kabupaten Blitar dalam rangka mencapai tujuan dan sasaran program dan kegiatan dalam bidang pencegahan khususnya di wilayah Wlingi akan diuraikan pada Tabel $1 .^{12}$

Tabel 1. Komponen Kegiatan Bidang Pencegahan di Kecamatan Wlingi Kabupaten Blitar Tahun 2016

\begin{tabular}{|c|c|c|}
\hline No & Komponen Kegiatan & Jumlah Kegiatan \\
\hline 1 & $\begin{array}{l}\text { Penyelenggaraan Advokasi Pembangunan Berwawasan Anti } \\
\text { Narkoba di Lingkungan Masyarakat Institusi Pendidikan }\end{array}$ & $5 x$ \\
\hline 2 & Penyelenggaraan Pemberdayaan Alternatif & $3 x$ \\
\hline 3 & $\begin{array}{l}\text { Penyelenggaraan Desiminasi Informasi } \\
\text { Keluarga, Pelajar dan Masyarakat }\end{array}$ & $28 x$ \\
\hline 4 & Pemberdayaan Peran Serta Masyarakat & $5 x$ \\
\hline 5 & $\begin{array}{l}\text { Diseminasi Informasi P4GN Melalui Tatap Muka di Sekolah- } \\
\text { sekolah }\end{array}$ & $3 x$ \\
\hline 6 & $\begin{array}{l}\text { Pelaksanaan Test Urine di Lingkungan Masyarakat dan } \\
\text { Pelajar }\end{array}$ & $1 \mathrm{x}$ \\
\hline 7 & Kampanye Anti Narkoba & $7 x$ \\
\hline
\end{tabular}

Berdasarkan Tabel 1, dapat diketahui bahwa upaya pencegahan penyalahgunaan narkoba di ruang lingkup sekolah di kecamatan Wlingi dilakukan melalui kegiatan diseminasi informasi P4GN melalui tatap muka di sekolah-sekolah wilayah Wlingi. Diseminasi informasi adalah suatu kegiatan yang ditujukan kepada kelompok target atau individu agar saran tersebut memperoleh informasi, timbul kesadaran, menerima, dan

${ }_{11}$ Moleong, J. Lexy 2009. Meteodologi Penelitian Kualitatif. Bandung: Remadja Rosdakarya. hlm 248.

${ }^{12}$ Data diperoleh dari BNN Kabupaten Blitar. 
akhirnya memanfaatkan informasi tersebut. Diseminasi informasi P4GN melalui tatap muka disekolah-sekolah pada tahun 2016 dilaksanakan kepada sekolah-sekolah sebanyak 2 kali pada sasaran pelajar sebanyak 50 siswa. Kegiatan diseminasi informasi P4GN melalui kegiatan tatap muka di kecamatan Wlingi akan disajikan pada Tabel 2.

Tabel 2. Diseminasi Informasi P4GN melalui Tatap Muka

\begin{tabular}{|l|l|l|}
\hline \multicolumn{1}{|c|}{ Tanggal } & \multicolumn{1}{|c|}{ Kegiatan } & \multicolumn{1}{c|}{ Peserta } \\
\hline 04 Maret 2016 & $\begin{array}{l}\text { Diseminasi Informasi P4GN melalui Tatap } \\
\text { Muka di SMPN 2 Wlingi }\end{array}$ & siswa \\
\hline 11 Maret 2016 & $\begin{array}{l}\text { Diseminasi Informasi P4GN melalui Tatap } \\
\text { Muka di MAN Wlingi }\end{array}$ & siswa \\
\hline
\end{tabular}

Diseminasi informasi adalah suatu kegiatan yang ditujukan kepada kelompok target atau individu agar memperoleh informasi, timbul kesadaran menerima, dan akhirnya memanfaatkan informasi tersebut. Diseminasi informasi bisa diartikan sebagai penyuluhan atau sosialisasi tatap muka yang dilakukan bidang pencegahan BNN Kabupaten Blitar terhadap sekolah-sekolah yang ada diwilayah Wlingi. Diseminasi informasi dilakukan oleh bidang pencegahan yang diwakili kepala bidang pencegahan yaitu Bapak Slamet Susanto, S.H,M.Si yang didampingi oleh dua orang yang bertugas sebagai penyuluh yaitu Sri Wahyuningsih, S.Sos dan Anindhita Rustiyan,S.Ikom. Kegiatan diseminasi informasi pada ruang lingkup sekolah di Kecamatan Wlingi akan diuaraikan sebagai berikut.

Kegiatan diseminasi informasi P4GN yang dilakukan oleh BNN Kabupaten Blitar ini dilakukan dalam rangka menindaklanjuti program Indonesia bebas Narkoba 2015. Peranan Badan Narkotika Nasional (BNN) Kabupaten Blitar Dalam Upaya Pencegahan Penyalahgunaan Narkoba Di Ruang Lingkup Sekolah Di Kecamatan Wlingi Kabupaten Blitar sudah sesuai dengan Peraturan Kepala Badan Narkotika Nasional Nomor 3 Tahun 2015 Tentang Organisasi dan Tata Kerja Badan Narkotika Nasional Provinsi Dan Badan Narkotika Nasional Kabupaten/Kota. Peranan Badan Narkotika Nasional (BNN) Kabupaten Blitar dalam Upaya Pencegahan Penyalahgunaan Narkoba Di Ruang Lingkup Sekolah Di Kecamatan Wlingi Kabupaten Blitar sudah baik karena tugas pokok dan fungsinya sedah sebagian besar terealisasi. Dengan terealisasinya program kerja Badan Narkotika Nasional (BNN) Kabupaten Blitar diharapkan bisa terwujudnya masyarakat Kabupaten Blitar yang bebas dari penyalahgunaan narokoba khususnya pada kalangan pelajar di ruang lingkup sekolah.

Dalam menjalankan visi, misi dan program kerjanya BNN Kabupaten Blitar bidang pencegahan mengalami beberapa hambatan/kendala, kendala tersebut terdiri dari kendala yang bersifat internal dan kendala yang bersifat eksternal. Kendala internal adalah faktor penghambat yang berasal dari pihak BNN Kabupaten Blitar khususnya Team Penyuluh pada bidang pencegahan. Berdasarkan hasil wawancara dengan Bapak Slamet Susanto, SH, MSi selaku kepala seksi pencegahan dan pemberdayaan masyarakat, saat ini seksi pencegahan dan pemberdayaan masyarakat memiliki anggota sebanyak 4 orang yang tediri dari penyuluh 2 orang, pengolah data 1 orang dan pengadministrasian umum 1 orang. Jika ditinjau dari segi kuantitas dalam melaksanakan tugas khususnya dalam bidang pencegahan diruang lingkup sekolah tentunya hal tersebut sangat jauh dari kondisi ideal. 
Kendala yang paling besar yaitu kendala sarana transportasi. Minimnya transportasi yang digunakan untuk menuju tempat penyuluhan membuat kualitas pelaksanaan kinerja Badan Narkotika Nasional Kabupaten (BNNK) Blitar kurang efektif. Berdasarkan data inventaris Badan Narkotika Nasional Kabupaten Blitar (BNNK) dapat diketahui bahwa sarana transportasi yang dimiliki oleh Badan Narkotika Nasional Kabupaten Blitar (BNNK) adalah 3 buah unit mobil yang terdiri dari 1 unit mobil Suzuki Carry (Pinjam dari PEMKAB), 1 unit mobil Kijang Inova, dan 1 unit mobil Suzuki APV, selain itu juga terdapat 2 unit motor Megapro. Jika ditinjau dari segi kuantitas jumlah tersebut jauh dari kondisi ideal. Minimnya kendaraan operasional tersebut tentunya akan berpengaruh terhadap keberhasilan upaya diseminasi informasi P4GN melalui kegiatan tatap muka di sekolahsekolah. Transportasi termasuk bagian penting untuk menunjang berbagai kegiatan, jika hal itu tidak terpenuhi, maka mustahil peran tersebut akan mencapai tujuannya.

Sedangkan kendala eksternal adalah faktor penghambat yang berasal dari luar, faktor ini dapat berasal dari pihak sekolah yaitu kepala sekolah, guru ataupun siswa. Kendalakendala tersebut diantaranya kurangnya pemahaman pihak sekolah terhadap kegiatan yang akan dilakukan oleh pihak BNN serta kurangnya motivasi siswa dalam mengikuti kegiatan diseminasi informasi P4GN (penyuluhan). Untuk mengatasi hal tersebut maka pihak BNN kabupaten Blitar menjelaskan terlebih dahulu kepada pihak sekolah maksud kedatangan pihak BNN ke sekolah yaitu pihak BNN akan melakukan kegiatan diseminasi informasi P4GN (penyuluhan) tentang narkoba dan bahaya narkoba.

\section{PENUTUP}

Berdasarkan uraian yang telah dikemukakan, maka penulis menarik kesimpulan bahwa Peranan Badan Narkotika Nasional (BNN) Kabupaten Blitar dalam upaya pencegahan penyalahgunaan narkoba di ruang lingkup sekolah di kecamatan Wlingi kabupaten Blitar sudah baik karena tugas pokok dan fungsinya sedah sebagian besar terealisasi. Upaya pencegahan penyalahgunaan narkoba di ruang lingkup sekolah di kecamatan Wlingi kabupaten Blitar dilakukan melalui kegiatan diseminasi informasi P4GN melalui tatap muka di sekolah-sekolah wilayah Wlingi. Sedangkan kendala-kendala yang dihadapi Badan Narkotika Nasional (BNN) kabupaten Blitar dalam upaya pencegahan penyalahgunaan narkoba di ruang lingkup sekolah di Kecamatan Wlingi kabupaten Blitar terdiri dari kendala internal dan kendala eksternal. Kendala internal berasal dari faktor internal hukum serta faktor sarana dan prasarana. Sedangkan kendala eksternal ini dapat berasal dari pihak sekolah yaitu kepala sekolah, guru ataupun siswa.

Dalam upaya meningkatkan kualitas kinerja Badan Narkotika Nasional Kabupaten Blitar di ruang lingkup sekolah di Kabupaten Blitar sebaiknya Badan Narkotika Nasional Kabupaten (BNNK) Blitar meningkatkan sarana dan prasarana guna mendukung kegiatan diseminasi informasi P4GN melalui kegiatan tatap muka di sekolah. Dalam menyajikan materi dilakukan dengan sebaik-baiknya dan menggunakan media yang dibuat semenarik mungkin agar siswa tidak bosan dan dapat merespon dengan baik, sehingga siswa dapat memahami dengan baik bahaya narkoba dan tidak akan menyalahgunakan narkoba. Sebaiknya di sekolah-sekolah juga dipasang spanduk himbauan tentang bahaya narkoba. Spanduk himbauan yang dipasang sebaiknya lebih menekankan pada efek atau dampak dari penyalahgunaan narkoba dan sebaiknya juga ditambah dengan gambar, sehingga 
dengan melihat gambar sudah mengerti apa maksud yang terkandung pada spanduk tersebut.

\section{DAFTAR PUSTAKA}

\section{Buku:}

Amirudin, Asikin, Z. 2004. Pengantar Metode Penelitian Hukum. Jakarta: PT Raja Grafindo Persada.

Ashsofa, B. 2004. Metode Penelitian Hukum. Jakarta: PT Rineka Cipta.

Bungin, Burhan. 2001. Metodelogi Penelitian Kualitatif, Jakarta: Rajawali.

Badan Narkotika Nasional. 2009. Pedoman Petugas Penyuluhan P4GN Dilingkungan Hukum. Jakarta: Badan Narkotika Nasional.

Heldy Chandra, dkk, Peranan Badan Narkotika Nasional Provinsi dalam Pencegahan dan Penanggulangan Peredaran Narkotika di Provinsi Sulawesi Selatan, artikel.

Joyo Nur Suryanto Gono, Narkoba: Bahaya Penyalahgunaan dan Pencegahannya, artikel.

Kadarmanta, A. Narkoba Pembunuh Karakter Bangsa. Jakarta: PT. Forum Media Utama.

Muhammad Al Imran. 2014. Efektivitas Kinerja Badan Narkotika Nasional Provinsi Sulawesi Selatan Dalam Upaya Pencegahan dan Pemberantasan Narkotika Dikalangan Remaja Kota Makassar. Skripsi. Universitas Hasanuddin Makassar.

Muhajir, H.N. 1996. Metodologi Penelitian Kualitatif. Edisi II, Yogyakarta: Rake Sarasin.

Moleong, J. Lexy 2009. Meteodologi Penelitian Kualitatif. Bandung: Remadja Rosdakarya.

\section{Peraturan Perundang-undangaan}

Undang-Undang Republik Indonesia Nomor 35 Tahun 2009 tentang Narkotika.

Peraturan Presiden Republik Indonesia Nomor 23 Tahun 2010 tentang Badan Narkotika Nasional.

Peraturan Kepala Badan Narkotika Nasional Nomor 3 Tahun 2015 tentang Organisasi dan Tata Kerja Badan Narkotika Nasional Provinsi dan Badan Narkotika Nasional Kabupaten/Kota 